\title{
Fermentation and elutriation of primary sludge: effect of SRT on process performance
}

\author{
A. Bouzas ${ }^{\mathrm{a}, *}$, J. Ribes ${ }^{\mathrm{a}}$, J. Ferrer ${ }^{\mathrm{b}}$ and A. Seco ${ }^{\mathrm{a}}$ \\ a Dpto. Ingeniería Química. Universidad de Valencia. Doctor Moliner 50. 46100. \\ Burjassot. Valencia. Spain. \\ b Dpto. Ingeniería Hidráulica y Medio Ambiente. Universidad Politécnica de Valencia. \\ Camino de Vera s/n. 46022. Valencia. Spain.
}

\begin{abstract}
A primary sludge fermentation-elutriation pilot plant was operated using in-line and side-stream schemes. The influence of solids retention time, recirculation sludge flow-rate and solids concentration on the fermentation-elutriation process performance has been assessed in this paper. The use of high elutriation flows (12\% of influent flow) improved the volatile fatty acids (VFA) concentration in the effluent stream. Suspended solids removal efficiency decreased in the primary settler when the solids retention time (SRT) was increased from 4 to 8 days. Disintegration step during hydrolysis process was pointed out as the main reason for that decrease. Maximum VFA productions were achieved at SRT between 6 and 8 days at the highest elutriation flow tested for both configurations. Propionic, butyric and valeric volatile fatty acids percentage increased when total solids sludge concentrations above $23000 \mathrm{mg} \cdot \mathrm{l}^{-1}$ were used. Hydrogen accumulation, causing acetogenic bacteria inhibition, was indicated as the reason for $\mathrm{C}_{3}-\mathrm{C}_{5}$ fatty acids accumulation.
\end{abstract}

\section{Keywords}

Pilot plant study; prefermentation; settler efficiency; sludge blanket; VFA composition.

\footnotetext{
* Corresponding author. Tel.: +34 96 3543434; Fax: +34 963544898

E-mail addresses: alberto.bouzas@uv.es (A. Bouzas), josep.ribes@uv.es (J. Ribes), aurora.seco@uv.es (A. Seco), jferrer@hma.upv.es (J.Ferrer).
} 


\section{Nomenclature}

\begin{tabular}{|c|c|}
\hline Alk & alkalinity \\
\hline APT & activated primary tank \\
\hline BNR & biological nutrient removal \\
\hline fns & non-settleable solids fraction \\
\hline GC & gas chromatography \\
\hline HAc & acetic acid \\
\hline $\mathrm{NH}_{4}-\mathrm{N}$ & ammonia nitrogen \\
\hline nsTSS & non-settable total suspended solids \\
\hline $\mathrm{PO}_{4}-\mathrm{P}$ & orthophosphate \\
\hline RSFR & recirculation sludge flow-rate \\
\hline SBCOD & soluble biological oxygen demand \\
\hline SBH & sludge blanket height \\
\hline SCOD & soluble chemical oxygen demand \\
\hline SRT & solid retention time \\
\hline SSR & suspended solids removal efficiency \\
\hline TBOD & total biological oxygen demand \\
\hline TCOD & total chemical oxygen demand \\
\hline TS & total solids \\
\hline TSS & total suspended solids \\
\hline TVS & total volatile solids \\
\hline VFA & volatile fatty acids \\
\hline VSS & volatile suspended solids \\
\hline WSFR & waste sludge flow-rate \\
\hline NV & ter treatment plant \\
\hline
\end{tabular}




\section{Introduction}

The number of wastewater treatment plants (WWTPs) equipped with biological nutrient removal (BNR) is increasing in Comunitat Valenciana (Spain). Many studies and practical experience have evidenced that high content of readily biodegradable chemical oxygen demand in the influent wastewater is needed to promote BNR in an activated sludge process (Maurer et al., 1997; Pitman et al., 1992). Besides, volatile fatty acids (VFA) have been demonstrated to be the most suitable carbon substrate for the biological phosphorus removal process (Barnard, 1984; Gerber et al., 1987).

Municipal wastewater has been shown as a potential source of readily biodegradable organic matter. Thus, acid fermentation of primary sludge as a VFA source has been the subject of several investigations (Danesh and Oleszkiewicz, 1997; Moser-Engeler et al., 1998; Bouzas et al., 2002). Several schemes of operation have been reported for VFA production from primary sludge fermentation (Pitman et al., 1992; Teichgräber, 2000). Full scale implementation includes both inline and side-stream prefermentation configurations. In-line process consists basically in allowing settled raw sludge solids to accumulate in the bottom of the primary settler tanks and recycling partially this sludge to elutriate the fermentation products out of the sludge (Barnard, 1984). On the other hand, side-stream configurations, with primary sludge feeding, usually comprise a two-stage operation: a separate complete-mix fermenter coupled to either a thickener or a primary settler in order to attain VFA elutriation (Münch and Koch, 1999; Rössle and Pretorius, 2001). In both configurations part of the accumulated sludge is purged to avoid the VFA consumption by methane formation.

The main objective of this study was to determine the optimal operating conditions of primary sludge fermentation-elutriation process. The experiments were conducted in a pilot plant fed with $40 \mathrm{l} \cdot \mathrm{h}^{-1}$ of municipal raw wastewater drawn from the degritter of the Carraixet WWTP in Valencia, 
Spain. The influence of solids retention time (SRT), recirculation sludge flow-rate (RSFR) and solids concentration on the process performance has been investigated. The two most common configurations have been used: a primary settler tank, usually known as activated primary tank (APT), and a complete-mix fermenter coupled to a primary settler.

\section{Materials and methods}

\subsection{Pilot plant description}

A pilot plant as represented in Fig. 1, with the characteristics shown in Table 1, was used in this research. The pilot plant consisted of a cylindrical equalization tank for wastewater characteristics homogenization, a primary settler provided with a bottom scraper and a stirred fermenter, all of them made of stainless steel. The bottom scraper was driven by a $1 \mathrm{rpm}$ electrical motor. The plant was thermally isolated with a $3 \mathrm{~cm}$ thick glass-fibre cover and the system was maintained at $20 \pm 1^{\circ} \mathrm{C}$ by means of a temperature controller. Peristaltic pumps and a piston pump were used to pump sludge and raw wastewater, respectively. The installation of manual valves allowed to study both side-stream and in-line configurations (see Fig. 1).

The side-stream configuration consisted of the primary settler coupled to the stirred fermenter. In this scheme, fermentation of primary sludge mainly takes place in the fermenter and the elutriation of VFA is carried out by recycling the fermented sludge to the primary settler. The SRT was controlled by wasting the appropriate volume from the fermenter by means of a temporized peristaltic pump. The fermenter configuration allowed to change very easily experimental conditions (solids and hydraulic retention times) by means of valves disposed in it (Fig.1).

The in-line configuration, the APT system, consisted of the primary settler where primary sludge was accumulated in order to induce its fermentation. The fermented sludge was drawn off from the 
bottom and recycled to elutriate the fermentation products out of the sludge. The sludge blanket level and the settler solids concentration were used to control the SRT, adjusting the waste sludge flow-rate (WSFR) properly.

The "nominal" SRT value, described in tables, was defined for both configurations as mass of solids in the fermentation volume divided by mass of solids per unit time wasted by means of the sludge purge. The fermentation volume in the APT system was the volume of the settler occupied with sludge. In the side-stream configuration the "nominal” SRT was calculated considering the sludge volume in the fermenter, because a negligible sludge quantity was kept in the primary settler.

\subsection{Sampling and measurements}

The sampling program was focused on the assessment of primary settling and fermentation process performance. Daily wastewater composite samples were collected by automatic dosing pumps placed at the homogenization tank and after the primary settler. These integrated samples were kept at $4^{\circ} \mathrm{C}$ in a refrigerator. Three times a week the fermented sludge was analyzed for the main parameters.

The following parameters were analysed to characterize the influent and effluent streams: total suspended solids (TSS), volatile suspended solids (VSS), total and soluble chemical oxygen demand (TCOD and SCOD), total and soluble biological oxygen demand (TBOD and SBOD), VFA, ammonia nitrogen $\left(\mathrm{NH}_{4}-\mathrm{N}\right)$, orthophosphate $\left(\mathrm{PO}_{4}-\mathrm{P}\right)$ and alkalinity (Alk). Total solids (TS), total volatile solids (TVS), TCOD and SCOD, VFA, $\mathrm{NH}_{4}-\mathrm{N}, \mathrm{PO}_{4}-\mathrm{P}$ and alkalinity were determined for fermented sludge characterisation. 
Temperature and $\mathrm{pH}$ on-line measurements were taken from influent, effluent and fermented sludge. A perforated glass twig was used as a prospection probe in order to obtain the sludge blanket level in the settler.

\subsection{Analytical methods}

Solids, COD, nitrogen and phosphorus determinations were performed according to Standard Methods (APHA, 1998). VFA concentration and the carbonate alkalinity were determined by titration according to the method proposed by WRC (1992). BOD was determined by pressure measurements using a WTW Oxitop Control 100 system. VFA composition was determined using a gas chromatography (GC) system (Varian Star 3400 CX) equipped with a flame ionization detector (FID). The GC column used was a free fatty acid phase (FFAP) capillary column $(15 \mathrm{~m} \times 0.53 \mathrm{~mm}$ I.D., film thickness $1 \mu \mathrm{m})$ from Tracer ${ }^{\circledR}$. The GC parameters are quoted next: injection port temperature $200^{\circ} \mathrm{C}$, detector temperature $200^{\circ} \mathrm{C}$, oven temperature ramp $100-120^{\circ} \mathrm{C}$ at $20^{\circ} \mathrm{C} \cdot \mathrm{min}^{-1}$ and $120-170^{\circ} \mathrm{C}$ at $10^{\circ} \mathrm{C} \cdot \mathrm{min}^{-1}$, helium gas flow rate $20 \mathrm{ml} \cdot \mathrm{min}^{-1}$.

\subsection{Experimental procedure}

The great number of factors affecting the fermentation-elutriation process performance makes it necessary to carry out experimental studies in order to establish the optimum conditions. Previous to this pilot plant study, laboratory bench-scale experiments were conducted using stirred reactors of 2.77 l (Bouzas et al., 2002). Two primary sludges from different WWTP were used in the benchscale experiments in order to examine VFA yield at different SRT, solids concentrations and temperatures. SRT ranged between 4 days and 10 days. Solids concentration was varied in the range $1 \%$ to $5 \%$. The reactors were incubated at constant temperature of $20^{\circ} \mathrm{C} \pm 0.5^{\circ} \mathrm{C}$ and $30^{\circ} \pm 0.5^{\circ} \mathrm{C}$. No elutriation was provided in these lab experiments. Three main conclusions were obtained from laboratory experiments results: sludge characteristics, as SCOD/TCOD and VFA/SCOD ratios of 
fed sludge, had an important influence on the efficiency of VFA production; the VFA production augmented when the SRT was increased from 4 to 8 days; and low solids concentration affected negatively the fermentation process. The results obtained in this preliminary study were used to establish the pilot plant experimental procedure presented in this paper.

Thirteen different operating conditions were tested on the pilot plant using the two prefermenter configurations described before and varying the SRT and RSFR parameters. Table 2 provides a summary of the operation conditions of the different runs carried out. For each experiment, the system was operated a minimum of three times the SRT value, assuming that stationary condition was achieved when variation in the net VFA production and TS was less than $10 \%$. Runs "S\#” were performed using the in-line configuration and runs "F\#" were performed using the side-stream configuration. Experiments S1, S2 and S3 were carried out at SRT of 7 and 8 days using two different RSFR (1.5 and $2.0 \mathrm{l} \cdot \mathrm{h}^{-1}$ ). Experiments F1 to F10 were carried out at three SRT (4, 6 and 8 days) varying the RSFR between 1.5 and $4.5 \mathrm{l} \cdot \mathrm{h}^{-1}$.

Although the main objective in the fermentation-elutriation process is to maximize the availability of soluble organic matter, especially in the form of volatile fatty acids, the phosphorus and nitrogen increase as well as the settling characteristics were taken into account.

\section{Results and discussion}

The influent and effluent wastewater characteristics and the fermented sludge characteristics for each experiment are summarised in Table 3 and Table 4 respectively. The data included in these tables represent the mean values once the stationary conditions were reached. The Carraixet WWTP usually receives industrial discharges which have an important influence on the wastewater quality. The influent wastewater characterization reflects a soluble organic matter percentage in the influent wastewater (about 31\%) lower than typical urban wastewater values. Furthermore, the VFA 
concentration in the influent shows low values, which highlights the importance of primary sludge fermentation in order to improve biological nutrient removal.

Table 5 summarises the principal parameters to determine the fermentation-elutriation process efficiency. Variation of main parameters, defined as an increase $(\Delta)$ or a decrease $(\nabla)$ in the effluent concentration respect to the influent concentration has been calculated.

\subsection{VFA production}

\subsubsection{Side-stream configuration}

Fig. 2 shows the VFA concentration in the fermented sludge and the VFA increase in the process. Even if the influent characteristics were not exactly similar in all the experiments, it is possible to observe that a RSFR increase improves the VFA elutriation because the VFA concentration in the effluent increases whereas the VFA concentration in the fermented sludge lessens. Experiments F4, F8 and F10, conducted at a RSFR of $4.5 \mathrm{l} \cdot \mathrm{h}^{-1}$ (12\% of influent flow, approximately), showed the highest values of VFA production.

Concerning the SRT, for runs performed at RSFR of 2 and $3 \mathrm{l} \cdot \mathrm{h}^{-1}$, the SRT increase caused a slight decrease in the VFA production. On the other hand, for runs performed at RSFR of 1.5 and $4.5 \mathrm{l} \cdot \mathrm{h}^{-1}$, the SRT increase improved the VFA production. Therefore, it is difficult to conclude that SRT has an actual positive or negative influence on the primary sludge fermentation-elutriation process because the differences between the values of VFA production are weak and the influent characteristics were not exactly similar between the runs.

Normally, the SRT increase should have improved the VFA production as it had been obtained in laboratory experiments. The different behaviour between laboratory and pilot plant experiments made it necessary to analyse other factors that could affect the fermentation-elutriation process. The 
explanation for this behaviour was found on the quantity of solids leaving the settler and will be discussed in more detail later.

In the side-stream experiments, the highest VFA increase was $36 \mathrm{mgHAc} \cdot \mathrm{l}^{-1}$ and it was achieved at SRT of 6 days using the highest RSFR value. Biological phosphorus removal studies carried out with the same influent wastewater in a biological nutrient removal pilot plant connected to the fermentation pilot plant, have shown a VFA-soluble phosphorus removal ratio of $8.0 \pm 1.2$ $\mathrm{mgHAc} \cdot \mathrm{mg}^{-1} \mathrm{P}$. This ratio agrees with literature values (Elefsioniotis and Oldman, 1994; Mavinic et al., 2000). Considering this ratio and the maximum VFA increase obtained in the experiments, nearly $4 \mathrm{mgP} \cdot \mathrm{l}^{-1}$ could be removed by means of primary sludge fermentation for the studied wastewater.

\subsubsection{In-line configuration}

High TS concentrations were obtained in the three in-line experiments within the SRT range studied in the side-stream experiments. An elevated sludge blanket height (SBH) in the settler was necessary to reach these SRT (Table 6). The high solids concentration values reached in the experiments S1, S2 and S3 produced a high VFA content in the fermented sludge. Nevertheless the VFA sludge concentrations for in-line experiments were not much higher than those obtained for the side-stream experiments operated at similar SRT and RSFR but lower solids concentration (runs F5, F6 and F9). The VFA increase in the effluent stream was always lower than 23 mgHAc $\mathrm{l}^{-1}$.

\subsection{Suspended solids removal}

The carryover of solids from primary sludge elutriation can be of advantage to plants having a weak settled wastewater, but can easily overload others. Therefore, the settling characteristics become an important parameter in order to establish the optimum conditions for fermentation-elutriation processes. 
Settling characteristics were analysed in the pilot plant in order to assess the settler efficiency without elutriation of the fermented sludge. Suspended solids removal efficiency (SSR), expressed as a percentage of the influent solids removed in the settler, was determined. The results led to suspended solids removal efficiency around 65\%. This value is in accordance with those reported for primary settlers without elutriation which range between 50 and 65\% (Vesilind, 2003).

The settling characteristics (see Table 6) during fermentation-elutriation process were evaluated in each experiment assessing the following parameters:

- SSR: suspended solids removal efficiency, defined above.

- SBH: sludge blanket height in the settler.

- fnsinfluent: influent non-settleable solids fraction, experimentally determined by means of settling assays (Ribes, 2004).

- fnseffluent: Effluent non-settleable solids fraction, calculated as the ratio between the effluent suspended solids and the influent suspended solids.

- $\Delta$ nsTSS (non-settleable solids concentration increase $)=\mathrm{TSS}_{\text {influent }} \cdot\left(\right.$ fns $_{\text {effluent }}-$ fnsinfluent $) \cdot 10^{-2}$

In the in-line configuration experiments, the low SSR values obtained (below 35\%) could be attributed to the high sludge blanket levels (around 1/2 of settler total height) which can facilitate solids carryover.

In the side-stream experiments, SSR was between 55 and $65 \%$ for the runs F1 to F4. These percentages are similar to those obtained without elutriation. However, the SSR obtained for the runs F6 to F10 showed low values, between 35 and 45\%, close to the values obtained in the in-line configuration experiments. 
- The difference between F1-F4 and F6-F10 can not be attributed to the influent SS concentration neither to the sludge blanket level because these two parameters were relatively constant: influent SS concentration showed a mean value of $216 \mathrm{mg} \cdot \mathrm{l}^{-1}$ (31.2 standard deviation) and SBH remained at low values (below 1/4 of settler total height).

- Regarding the experiments performed at the same RSFR (see Table 6), it can be observed that the SSR lessened as the SRT was increased. Runs performed at 4 days of SRT showed a mean SSR value around $62 \pm 3 \%$. This SSR value fell off approximately until $46 \pm 4 \%$ when the SRT was increased up to 6 days. The runs carried out at 8 days of SRT showed a SSR value around $36 \pm 2 \%$.

Considering these results, the settling characteristics deterioration has been put down to the increase of SRT value and to the particulate organic matter disintegration process. The degradation of particulate material in primary sludge fermentation can be divided into two steps: disintegration and extracellular hydrolysis steps. The disintegration step includes a variety of processes such as lysis, non-enzymatic decay and physical breakdown (Batstone et al., 2002), so complex raw particulate organic matter is disintegrated into simpler products with smaller particle size. Products of disintegration show a simpler molecular structure and as a result, during the elutriation process, they would be easily carried over on account of their low settling velocity. Thus, the non-settleable solids concentration would increase. This disintegration step would be favoured at high SRT values because of particulate organic matter remains in the system longer. In Fig. 3, the variation of the non-settleable solids concentration in the side-stream experiments has been depicted. In this figure it can be observed that the non-settleable solids undergo a steeply increase when the SRT changes from 4 to 8 days. 
On balance, the use of high SRT, up to 8 days, enhances the fermentation process when fermented sludge is not elutriated in a primary settler, as it was previously observed in laboratory experiments (Bouzas et al, 2002). However, when elutriation takes place, the use of high SRT will not mean higher VFA productions. The non-settleable solids increase, due to the disintegration processes, will reduce the "nominal" SRT and the fermentation-elutriation process results will be affected. The low settling efficiency achieved at SRT higher than 4 days will have a great effect on fermentationelutriation systems. This effect should be considered to set the optimum performance conditions.

\subsection{VFA composition}

The composition of the VFA produced would be an important factor to improve biological phosphorus removal in the WWTP, since not all the VFA lead to the same phosphorous removal efficiencies. Acetic acid has been pointed out as the best carbon source for the biological phosphorous removal followed by propionic acid (Moser-Engeler et al., 1998; Oehmen et al., 2004). This fact highlights the importance of the composition of the VFA obtained in the fermentationelutriation process.

Samples obtained from fermented sludge were analysed by GC in order to obtain the VFA composition. The VFA composition was divided into three fractions: acetic acid, propionic acid and $\mathrm{C}_{4}-\mathrm{C}_{5}$ acids (n-butyric, iso-butyric, methyl butyric and n-valeric).

The chromatographic results (see Fig. 4) showed a dependence of VFA composition on TS concentration. Acetic acid percentage decreased at high TS concentrations whereas propionic acid percentage and $\mathrm{C}_{4}-\mathrm{C}_{5}$ acids percentage increased, irrespective of the studied configuration. The same dependence had already been observed in laboratory bench-scale experiments (Bouzas et al., 2002). 
The in-line configuration experiments (S1, S2 and S3), carried out at high solids concentration (TS $\approx 40000 \mathrm{mg} \cdot \mathrm{l}^{-1}$ ), showed a similar VFA composition on an acetic acid basis: $74 \%$ of acetic acid, $14 \%$ of propionic acid and $11 \%$ of $\mathrm{C}_{4}-\mathrm{C}_{5}$ acids. Regarding the side-stream configuration

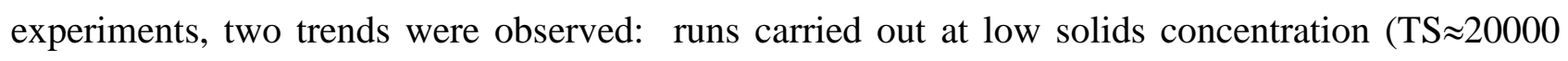
$\mathrm{mg} \cdot \mathrm{l}^{-1}$ ) showed a high percentage of acetic acid, about 91\%; on the contrary, run F5 performed at higher solids concentration (TS $27000 \mathrm{mg} \cdot \mathrm{l}^{-1}$ ) showed lower acetic acid percentage (about $72 \%$ ) and higher propionic and $\mathrm{C}_{4}-\mathrm{C}_{5}$ percentages.

The acetogenesis step, where long volatile fatty acids are converted into acetic acid and hydrogen by acetogenic bacteria, can only takes place at low hydrogen partial pressures (Leslie Grady et al., 1999). Thus, when the hydrogen partial pressure is high, this conversion will not proceed causing long chain volatile fatty acids accumulation. In anaerobic digestion processes, the hydrogen partial pressure is kept low by the action of methanogenic bacteria. Nevertheless, the presence of methanogens in primary sludge fermentation has to be avoided in order to prevent acetic acid conversion into methane. Therefore, hydrogen partial pressure could reach high values in prefermentation systems.

The use of high SRT and TS concentration values increases the VFA generation (Bouzas et al., 2002) and consequently the hydrogen formation. So, high TS concentrations and low RSFR can lead to inhibitory hydrogen levels for acetogens. As a consequence, $C_{3}-C_{5}$ acids accumulation takes place. As can be seen in Fig. 4, the degradation of VFA with three or more C atoms seems to be inhibited at TS concentrations above $23000 \mathrm{mg} \cdot \mathrm{l}^{-1}$. 
These results reflect the importance of the prefermentation scheme: in-line schemes, working under high TS concentrations in order to increase VFA generation, lead to a lessening in the acetic acid production. On the other hand, side-stream configurations lead to a greater acetic acid production.

\section{4. $\mathrm{N}, \mathrm{P}$ and $\mathrm{pH}$ variations}

The degradation of organic nitrogen and phosphorus causes ammonia and phosphate release during the fermentation process. Further release to the liquid phase occurs during the elutriation process and, as a consequence, an increase in phosphate and ammonia concentration was observed. The increase for both parameters in all the experiments carried out was not significant compared with the influent values (see tables 3 and 5). The phosphate increase never exceeded $1 \mathrm{mgP} \cdot \mathrm{l}^{-1}$ and the ammonia increase ranged from 0.3 to $3.8 \mathrm{mgN} \cdot \mathrm{l}^{-1}$, irrespective of the SRT selected or even of the studied configuration.

The effluent $\mathrm{pH}$ was not significantly affected by the experiment conditions showing a slight drop from the influent value. The $\mathrm{pH}$ decrease was always lower than 0.2 units for all the experiments carried out. The $\mathrm{pH}$ value in the fermented sludge remained in the range of 6.8 to 7.2. The moderate VFA increase and the high alkalinity concentration avoided great $\mathrm{pH}$ variations.

\section{Conclusions}

Primary sludge fermentation process was investigated in this work using a pilot plant fed with municipal wastewater. Thirteen different operating conditions were tested using two prefermenter configurations and varying the SRT and RSFR parameters.

For both configurations, in-line and side-stream, the use of high RSFR improved the VFA concentration in the effluent stream and caused a low decrease in the settling characteristics. 
The use of high SRT affects negatively the organic matter sedimentation and does not improve systematically the VFA production. In the side-stream experiments the suspended solids reduction value decreased from $65 \%$ to $34 \%$ when the SRT was raised from 4 to 8 days. Low settler efficiency values, around 30\%, were also found in the in-line configuration experiments carried out at high SRT. Disintegration process was pointed out as the main reason for the decrease in primary settling efficiency at high SRT. This lower settling efficiency causes a decrease in the effective SRT value and consequently affects the VFA production.

The maximum VFA increase obtained in the side-stream experiments was about $36 \mathrm{mgHAc} \cdot \mathrm{l}^{-1}$. This value was achieved at SRT of 6 days using the highest RSFR value. The maximum VFA production in the in-line experiments was lower than $23 \mathrm{mgHAc} \cdot \mathrm{l}^{-1}$. This value was lower than VFA production obtained for the side-stream experiments operated at similar SRT and RSFR. Although APT systems are the simplest prefermentation configuration, both the lower VFA production and the poor suspended solids removal become an important drawback.

The chromatographic results showed a dependence of VFA composition on TS sludge concentration. Irrespective of the studied configuration, acetic acid percentage decreased at high TS sludge concentration.

The fermentation-elutriation process resulted in no significant increase in soluble phosphorus and ammonia. No influence of SRT or configuration process on phosphorus and ammonia productions was detected from experimental results. Furthermore, low variations in the effluent $\mathrm{pH}$ values were observed. 


\section{Acknowledgements}

This research work has been supported by the Spanish Research Foundation (CICYT, project AMB1998-0881), which is gratefully acknowledged. Technical support from Entidad Pública de Saneamiento de Aguas Residuales de la Comunidad Valenciana is also gratefully acknowledged.

\section{REFERENCES}

APHA 1998. Standard Methods for the Examination of Water and Wastewater . $20^{\text {th }}$ edn, American Public Health Association, American Water Works Association and Water Environment Federation, Washington DC, USA.

Barnard, J.L., 1984. Activated primary tanks for phosphate removal. Water SA 10, 121-126.

Batstone, D.J.; Keller, P.; Angelidaki, I.; Kalyuzhnyi, S.V.; Pavlostathis, S.G.; Rozzi, A.; Sanders, W.T.M.; Siegrist, H.; Vavilin, V.A., 2002. Anaerobic Digestion Model No. 1, IWA Scientific and Technical Report No. 13, IWA, London. ISBN 1900222787.

Bouzas, A., Gabaldón, C., Marzal, P., Penya-Roja, J.M. and Seco, A., 2002. Fermentation of municipal primary sludge: effect of SRT and solids concentration on volatile fatty acid production. Environ. Technol. 23, 863-875.

Danesh, S. and Oleszkiewicz, J.A., 1997. Volatile fatty acid production and uptake in biological nutrient removal systems with process separation. Water Environ. Res. 69, 1106-1111.

Elefsiniotis, P. and Oldham, W.K., 1994. Substrate degradation patterns in acid-phase anaerobic digestion of municipal primary sludge. Environ. Technol. 15, 741-751.

Leslie Grady, C.P., Daigger, G.T. and Lim, H.C., 1999. Biological Wastewater Treatment. 2nd Edition, Marcel Dekker, Inc., New York, NY,.

Gerber, A. Mostert, E.S., Winter, C.T. and Villiers, R.H., 1987. Interactions between phosphate, nitrate and organic substrate in biological nutrient removal processes. Water Sci. Technol. 19, 1873-1894. 
Maurer, M., Gujer, W., Hany, R. and Bachmann, S., 1997. Intracellular carbon flow in phosphorus accumulating organisms from activated sludge. Water Res. 31(4), 907-917.

Mavinic, D.S., Mahendraker, V., Doucette, D., Rabinowitz, B., Barnard, J.L. and Koch, F.A., 2000. Feasibility of using high-rate, on-line, fixed-film fermenters for SCVFA generation in a BNR process train. Environ. Technol. 21, 941-952.

Moser-Engeler, R., Udert, K.M., Wild, D. and Siegrist, H., 1998. Products from primary sludge fermentation and their suitability for nutrient removal. Water Sci. Technol. 38, 265-273.

Münch, E.v. and Koch, F.A., 1999. A survey of prefermenter design, operation and performance in Australia and Canada. Water Sci. Technol. 39, 105-112.

Oehmen, A. Yuan, Z., Blackall, L., Keller, J., 2004. Short-term effects of carbon source on the competition of polyphosphate accumulating organisms and glycogen accumulating organisms. Proceedings of $3^{\text {rd }}$ IWA Specialised Conference on sequencing Batch Reactor Technology (SBR3). Noosa, Queensland, Australia.

Pitman, A.R., Lötter, L.H., Alexander, W.V. and Deacon, S.L., 1992. Fermentation of raw sludge and elutriation of resultant fatty acids to promote excess biological phosphorus removal. Water Sci. Technol. 25(4-5), 185-194.

Ribes, J., 2004. Settlers modelling in wastewaters treatment plants. Application to the primary sludge fermentation-elutriation process. PhD thesis. University of Valencia. (in Spanish).

Rössle, W.H.; Pretorius, W.A., 2001. A review of characterisation requirements for in-line prefermenters Paper 2: Process characterisation. Water SA 27(3), 413-422.

Teichgräber, B., 2000. Acidification of primary sludge to promote increased biological phosphorus elimination and denitrification. Water Sci. Technol. 41(9), 163-170.

Vesilind, P.A. 2003. Wastewater Treatment Plant Design. Water Environment Federation, Alexandria, VA. ISBN 1843390248. 
Water Research Commission. 1992. Simple titration procedures to determine $\mathrm{H}_{2} \mathrm{CO}_{3}{ }^{*}$ alkalinity and short-chain fatty acids in aqueous solutions containing known concentrations of ammonium, phosphate and sulphide weak acid/bases, Report No. TT 57/92, Water Research Commission, University of Cape Town, Pretoria, Republic of South Africa. 


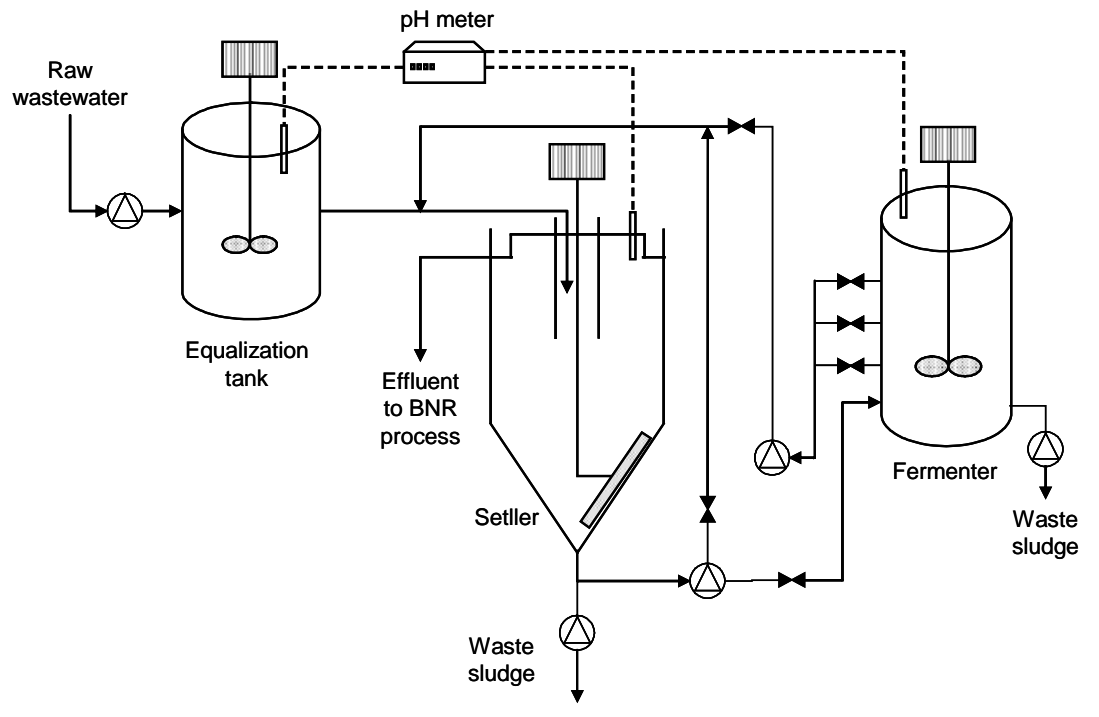

Figure 1 - Pilot plant schematic layout. 

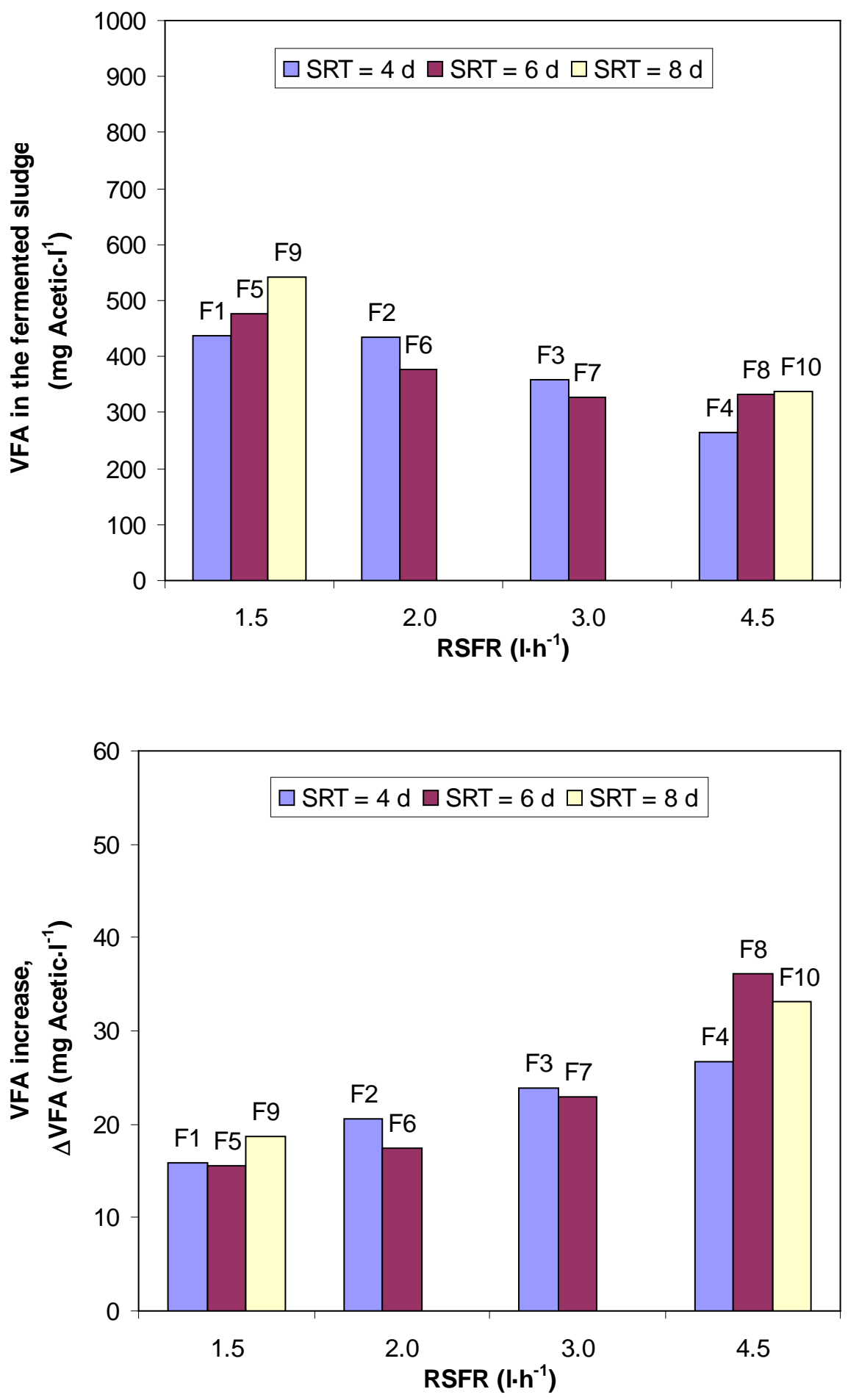

Figure 2 - VFA concentration in fermented sludge and VFA increase in the process. 


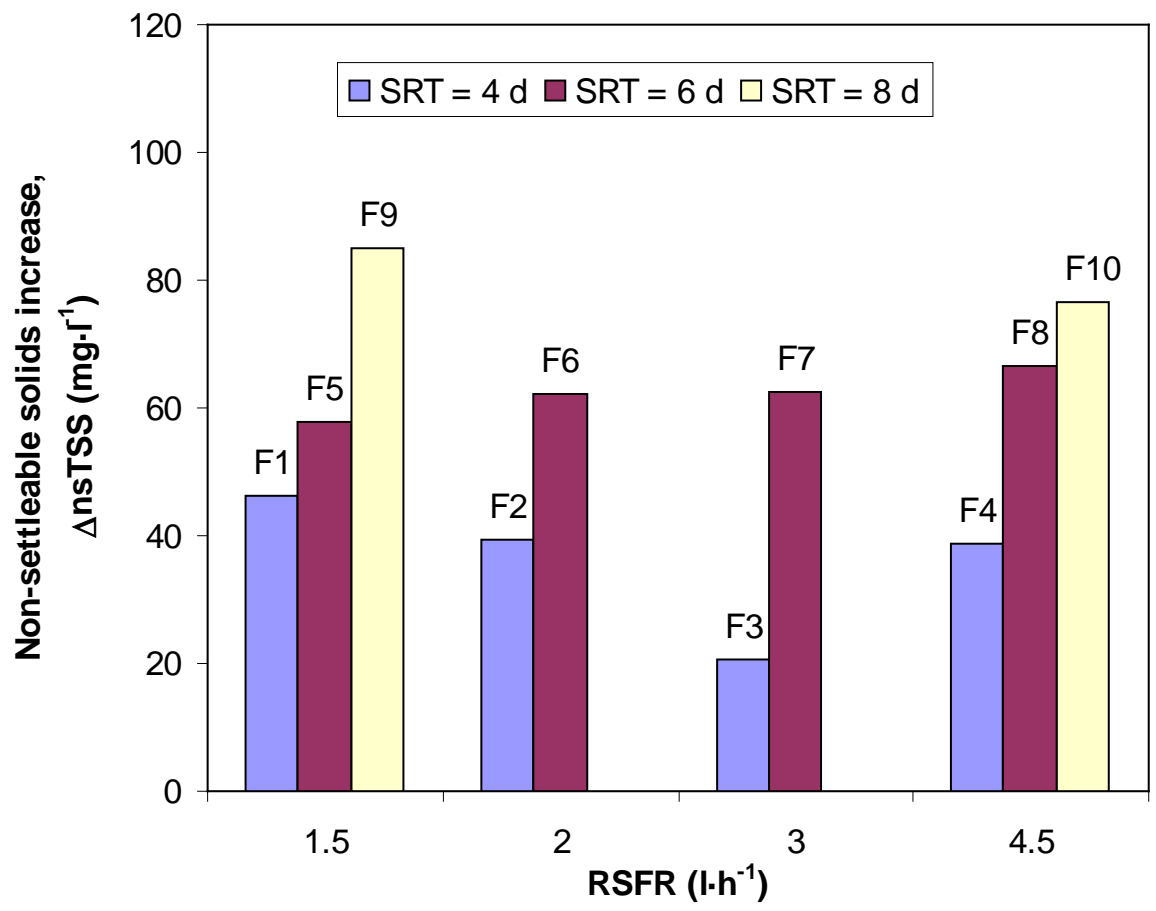

Figure 3 - Non-settleable solids concentration increase (Side-stream configuration). 


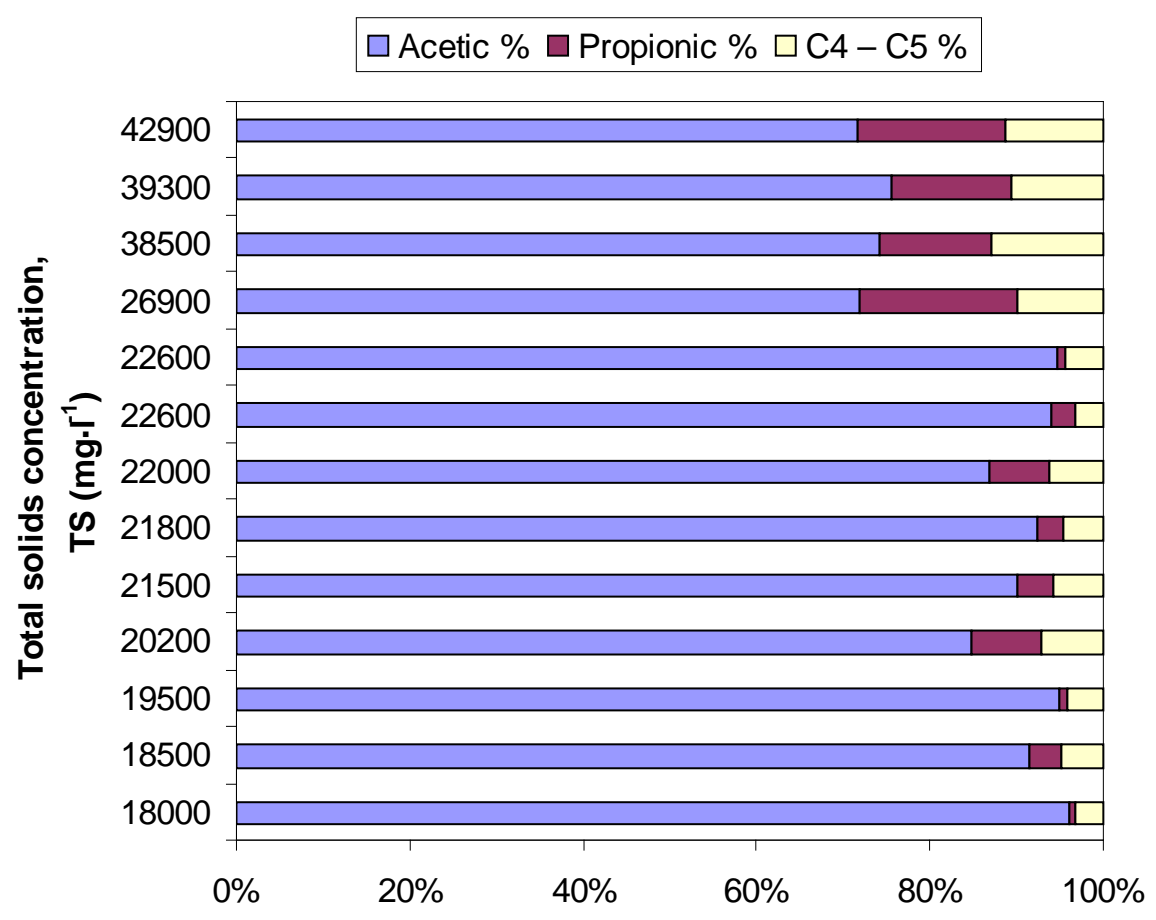

Figure 4 - Composition of the VFA fraction with respect to TS sludge concentration. 
Table 1 - Design characteristics of pilot plant elements.

\begin{tabular}{lcccc}
\hline Parameter & Units & $\begin{array}{c}\text { Equalization } \\
\text { tank }\end{array}$ & Settler & Fermenter \\
\hline Diameter & $\mathrm{m}$ & 0.4 & 0.50 & 0.40 \\
Total height & $\mathrm{m}$ & 0.8 & 0.90 & 0.65 \\
Conical part height & $\mathrm{m}$ & --- & 0.45 & --- \\
Conical part slope & $\%$ & --- & 173 & --- \\
Effective volume & $\mathrm{l}$ & 100 & 112 & 19 \\
\hline
\end{tabular}


Table 2 - Operational conditions.

\begin{tabular}{llccccccccccccc}
\hline Parameter & Units & S1 & S2 & S3 & F1 & F2 & F3 & F4 & F5 & F6 & F7 & F8 & F9 & F10 \\
\hline SRT & $\mathrm{d}$ & 7 & 7 & 8 & 4 & 4 & 4 & 4 & 6 & 6 & 6 & 6 & 8 & 8 \\
RSFR & $\mathrm{I} \mathrm{h}^{-1}$ & 1.5 & 2.0 & 2.0 & 1.5 & 2.0 & 3.0 & 4.5 & 1.5 & 2.0 & 3.0 & 4.5 & 1.5 & 4.5 \\
WSFR & $\mathrm{I} \mathrm{d}^{-1}$ & 1.8 & 1.8 & 1.5 & 4.8 & 4.8 & 4.8 & 4.8 & 3.0 & 3.0 & 3.0 & 3.0 & 2.4 & 2.4 \\
$\mathrm{~T}$ & ${ }^{\circ} \mathrm{C}$ & 20.0 & 20.0 & 20.0 & 20.0 & 20.0 & 21.7 & 20.0 & 20.0 & 20.0 & 20.0 & 20.8 & 20.0 & 20.6 \\
\hline
\end{tabular}


Table 3 - Influent and effluent wastewater characteristics.

\begin{tabular}{|c|c|c|c|c|c|c|c|c|c|c|c|c|c|c|}
\hline Parameter & Units & S1 & $\mathrm{S} 2$ & S3 & $\mathrm{F} 1$ & F2 & F3 & $\mathrm{F} 4$ & F5 & F6 & F7 & F8 & F9 & F10 \\
\hline \multicolumn{15}{|c|}{ Influent } \\
\hline TSS & $\mathrm{mg} \mathrm{l}^{-1}$ & 205 & 298 & 227 & 186 & 186 & 190 & 240 & 190 & 199 & 210 & 225 & 212 & 240 \\
\hline VSS & $\mathrm{mg} \mathrm{l}^{-1}$ & 139 & 203 & 138 & 131 & 135 & 137 & 167 & 136 & 139 & 153 & 164 & 163 & 184 \\
\hline TCOD & $\operatorname{mgCOD~}^{-1}$ & 342 & 473 & 382 & 341 & 346 & 294 & 400 & 352 & 365 & 362 & 390 & 445 & 460 \\
\hline SCOD & $\mathrm{mgCOD}^{-1}$ & 74 & 114 & 115 & 127 & 94 & 85 & 104 & 100 & 133 & 110 & 102 & 156 & 140 \\
\hline TBOD & $\mathrm{mgCOD} \mathrm{l}^{-1}$ & 190 & 372 & 276 & 202 & 223 & 225 & 270 & 276 & 250 & 210 & 248 & 280 & 334 \\
\hline SBOD & $\mathrm{mgCOD} \mathrm{l}^{-1}$ & 41 & 61 & 90 & 76 & 66 & 64 & 54 & 75 & 104 & 50 & 54 & 121 & 112 \\
\hline VFA & mgHAc l-1 $^{-1}$ & 8.5 & 16.2 & 5.8 & 2.5 & 2.7 & 7.0 & 2.0 & 6.4 & 4.0 & 1.0 & 1.4 & 5.6 & 2.5 \\
\hline $\mathrm{NH}_{4}-\mathrm{N}$ & $\mathrm{mgN} \mathrm{l}^{-1}$ & 34.6 & 37.7 & 34.5 & 21.9 & 23.3 & 24.7 & 28.0 & 22.0 & 37.2 & 33.8 & 23.0 & 33.0 & 36.2 \\
\hline $\mathrm{PO}_{4}-\mathrm{P}$ & $\operatorname{mgP~} \mathrm{l}^{-1}$ & 3.9 & 4.2 & 3.4 & 2.8 & 2.4 & 3.0 & 3.0 & 2.6 & 3.5 & 2.7 & 3.5 & 3.4 & 4.5 \\
\hline Alk & $\mathrm{mgCaCO}_{3} \mathrm{l}^{-1}$ & 406 & 404 & 418 & 357 & 351 & 313 & 370 & 370 & 393 & 311 & 309 & 371 & 352 \\
\hline $\mathrm{pH}$ & & 7.70 & 7.70 & 7.70 & 7.85 & 7.70 & 7.70 & 7.70 & 7.70 & 7.67 & 7.65 & 7.66 & 7.72 & 7.66 \\
\hline \multicolumn{15}{|c|}{ Effluent } \\
\hline TSS & $\mathrm{mg} \mathrm{l}^{-1}$ & 142 & 207 & 148 & 65 & 71 & 70 & 101 & 92 & 126 & 117 & 125 & 140 & 151 \\
\hline VSS & $\mathrm{mg} \mathrm{l}^{-1}$ & 96 & 137 & 94 & 53 & 58 & 55 & 74 & 71 & 105 & 86 & 93 & 108 & 118 \\
\hline TCOD & $\mathrm{mgCOD} \mathrm{l}^{-1}$ & 265 & 391 & 315 & 170 & 169 & 199 & 266 & 247 & 289 & 273 & 295 & 380 & 380 \\
\hline SCOD & $\mathrm{mgCOD} \mathrm{l}^{-1}$ & 95 & 162 & 140 & 144 & 119 & 120 & 145 & 131 & 154 & 140 & 142 & 176 & 182 \\
\hline TBOD & $\mathrm{mgCOD} \mathrm{l}^{-1}$ & 150 & 250 & 256 & 104 & 110 & 146 & 163 & 217 & 125 & 152 & 177 & 210 & 210 \\
\hline SBOD & $\mathrm{mgCOD} \mathrm{l}^{-1}$ & 62 & 109 & 115 & 87 & 91 & 89 & 95 & 106 & 93 & 80 & 90 & 135 & 140 \\
\hline VFA & mgHAc l-11 & 22.1 & 38.6 & 28.7 & 18.3 & 23.3 & 30.8 & 28.7 & 21.9 & 21.5 & 24.0 & 37.5 & 24.3 & 35.6 \\
\hline $\mathrm{NH}_{4}-\mathrm{N}$ & $\mathrm{mgN}^{-1}$ & 34.9 & 41.5 & 35.3 & 23.6 & 24.2 & 27.3 & 31.8 & 23.1 & 38.3 & 36.2 & 25.8 & 34.5 & 38.9 \\
\hline $\mathrm{PO}_{4}-\mathrm{P}$ & $\mathrm{mgP} \mathrm{l}^{-1}$ & 4.3 & 4.7 & 4.1 & 3.2 & 2.9 & 3.4 & 3.7 & 3.1 & 3.8 & 3.2 & 4.0 & 3.7 & 4.9 \\
\hline Alk & $\mathrm{mgCaCO}_{3} \mathrm{l}^{-1}$ & 400 & 415 & 417 & 365 & 350 & 352 & 380 & 384 & 391 & 333 & 324 & 393 & 378 \\
\hline $\mathrm{pH}$ & & 7.59 & 7.56 & 7.56 & 7.80 & 7.65 & 7.50 & 7.50 & 7.60 & 7.60 & 7.50 & 7.50 & 7.52 & 7.51 \\
\hline
\end{tabular}


Table 4 - Fermented sludge characteristics.

\begin{tabular}{|c|c|c|c|c|c|c|c|c|c|c|c|c|c|c|}
\hline Parameter & Units & S1 & $\mathrm{S} 2$ & S3 & F1 & F2 & F3 & F4 & F5 & F6 & F7 & F8 & F9 & F10 \\
\hline TS & $\mathrm{mg} \mathrm{l}^{-1}$ & 38500 & 39300 & 42900 & 22000 & 20200 & 18000 & 19500 & 26900 & 18500 & 21500 & 22600 & 21800 & 22600 \\
\hline TVS & $\mathrm{mg} \mathrm{l}^{-1}$ & 24400 & 24300 & 24500 & 12100 & 11900 & 10900 & 11700 & 15300 & 11900 & 13400 & 14300 & 14700 & 14800 \\
\hline TCOD & $\mathrm{mgCOD}^{-1}$ & 50195 & 41840 & 43716 & 22735 & 20452 & 19149 & 21321 & 28682 & 20415 & 22628 & 24803 & 27165 & 24706 \\
\hline SCOD & $\mathrm{mgCOD} \mathrm{l}^{-1}$ & 595 & 715 & 612 & 700 & 720 & 582 & 523 & 870 & 659 & 530 & 535 & 815 & 510 \\
\hline VFA & mgHAc l-1 $^{-1}$ & 426 & 503 & 476 & 437 & 434 & 359 & 265 & 477 & 376 & 327 & 333 & 541 & 338 \\
\hline $\mathrm{NH}_{4}-\mathrm{N}$ & $\mathrm{mgN} \mathrm{l}^{-1}$ & 66.9 & 98.1 & 91.8 & 45.2 & 48.9 & 49.7 & 49.2 & 59.6 & 65.6 & 52.9 & 41.4 & 61.9 & 51.1 \\
\hline $\mathrm{PO}_{4}-\mathrm{P}$ & $\mathrm{mgP} \mathrm{l}^{-1}$ & 10.1 & 10.4 & 9.9 & 8.7 & 9.5 & 6.8 & 5.9 & 9.0 & 9.8 & 7.2 & 8.1 & 8.8 & 7.6 \\
\hline Alk & $\mathrm{mgCaCO}_{3} \mathrm{l}^{-1}$ & 535 & 602 & 536 & 466 & 476 & 441 & 503 & 483 & 502 & 465 & 410 & 432 & 392 \\
\hline $\mathrm{pH}$ & & 7.10 & 7.10 & 6.80 & 7.10 & 7.10 & 7.17 & 7.24 & 6.90 & 7.10 & 7.18 & 7.10 & 7.10 & 7.14 \\
\hline
\end{tabular}


Table 5 - Fermentation-elutriation process results.

\begin{tabular}{llccccccccccccc}
\hline Parameter & Units & $\mathrm{S} 1$ & $\mathrm{~S} 2$ & $\mathrm{~S} 3$ & $\mathrm{~F} 1$ & $\mathrm{~F} 2$ & $\mathrm{~F} 3$ & $\mathrm{~F} 4$ & $\mathrm{~F} 5$ & F6 & F7 & F8 & F9 & F10 \\
\hline$\Delta \mathrm{SCOD}$ & mgCOD l$^{-1}$ & $21 \pm 8$ & $48 \pm 3$ & $25 \pm 2$ & $17 \pm 4$ & $25 \pm 3$ & $35 \pm 5$ & $41 \pm 3$ & $31 \pm 4$ & $21 \pm 3$ & $30 \pm 7$ & $40 \pm 2$ & $20 \pm 4$ & $42 \pm 2$ \\
$\Delta \mathrm{VFA}$ & m $^{-1} \mathrm{CAc} \mathrm{l}^{-1}$ & $13.6 \pm 0.4$ & $22.4 \pm 1.4$ & $22.9 \pm 0.8$ & $15.8 \pm 0.4$ & $20.6 \pm 0.7$ & $23.8 \pm 1.7$ & $26.7 \pm 0.2$ & $15.5 \pm 1.0$ & $17.5 \pm 1.1$ & $23.0 \pm 1.9$ & $36.1 \pm 0.8$ & $18.7 \pm 2.8$ & $33.1 \pm 0.5$ \\
$\Delta \mathrm{NH}_{4}-\mathrm{N}$ & $\mathrm{mgN} \mathrm{l}^{-1}$ & $0.3 \pm 0.6$ & $3.8 \pm 0.1$ & $0.8 \pm 0.1$ & $1.7 \pm 0.3$ & $0.9 \pm 0.2$ & $2.6 \pm 0.3$ & $3.8 \pm 0.1$ & $1.1 \pm 0.5$ & $1.1 \pm 0.4$ & $2.4 \pm 0.9$ & $2.8 \pm 1.5$ & $1.5 \pm 1.7$ & $2.7 \pm 0.3$ \\
$\Delta \mathrm{PO}_{4}-\mathrm{P}$ & $\mathrm{mgP} \mathrm{l}^{-1}$ & $0.4 \pm 0.1$ & $0.5 \pm 0.1$ & $0.7 \pm 0.4$ & $0.4 \pm 0.1$ & $0.5 \pm 0.1$ & $0.4 \pm 0.1$ & $0.7 \pm 0.3$ & $0.5 \pm 0.1$ & $0.3 \pm 0.4$ & $0.5 \pm 0.4$ & $0.5 \pm 0.1$ & $0.3 \pm 0.1$ & $0.4 \pm 0.2$ \\
$\nabla \mathrm{pH}$ & & 0.11 & 0.14 & 0.14 & 0.05 & 0.05 & 0.20 & 0.20 & 0.10 & 0.07 & 0.15 & 0.16 & 0.20 & 0.15 \\
\hline
\end{tabular}


Table 6 - Settling process characteristics.

\begin{tabular}{|c|c|c|c|c|c|c|c|c|c|c|c|c|c|c|}
\hline Parameter & Units & $\mathrm{S} 1$ & S2 & S3 & $\mathrm{F} 1$ & F2 & F3 & $\mathrm{F} 4$ & F5 & F6 & F7 & F8 & F9 & F10 \\
\hline SSR & $\%$ & 30.7 & 30.5 & 34.8 & 65.1 & 61.8 & 63.2 & 57.9 & 51.6 & 36.7 & 44.3 & 44.4 & 34.0 & 37.1 \\
\hline SBH & $\mathrm{m}$ & 0.41 & 0.41 & 0.42 & 0.14 & 0.14 & 0.13 & 0.22 & 0.14 & 0.14 & 0.14 & 0.22 & 0.14 & 0.23 \\
\hline fns $_{\text {influent }}$ & $\%$ & 24 & 26 & 20 & 10 & 17 & 26 & 26 & 18 & 32 & 26 & 26 & 26 & 31 \\
\hline fnS $_{\text {effluent }}$ & $\%$ & 69 & 69 & 65 & 35 & 38 & 37 & 42 & 48 & 63 & 56 & 56 & 66 & 63 \\
\hline$\Delta \mathrm{nsTSS}$ & $\mathrm{mg} \mathrm{l}^{-1}$ & 93 & 130 & 103 & 46 & 39 & 21 & 39 & 58 & 62 & 62 & 67 & 85 & 77 \\
\hline
\end{tabular}

